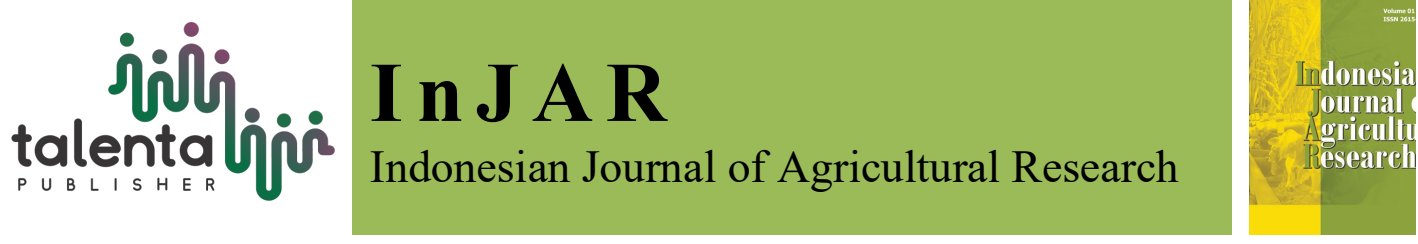

\title{
Farmers' Perception about Major Insect Pests of Cucurbits and Their Management
}

\author{
Subina Tripathi ${ }^{1 *}$, Kabita Kumari Shah ${ }^{2}$, Injila Tiwari ${ }^{3,}$ and Jiban \\ Shrestha ${ }^{4}$ \\ ${ }^{1}$ Himalayan College of Agricultural Science and Technology, Purbanchal University, Kathmandu, Nepal \\ ${ }^{2}$ Institute of Agriculture and Animal Science, Gokuleshwor College, Tribhuvan University, Baitadi, Nepal \\ ${ }^{3}$ Himalayan College of Agricultural Science and Technology, Purbanchal University, Kathmandu, Nepal \\ ${ }^{4}$ Nepal Agricultural Research Council, National Plant Breeding and Genetics Research Centre, \\ Khumaltar, Lalitpur, Nepal
}

\begin{abstract}
A survey was undertaken in five Village Development Committees (VDCs) of Lamjung District, Nepal from June to August 2018 to investigate major insect pests and their management practices in cucurbits. A total of ninety-five cucurbit growers were selected and interviewed using semi-structured questionnaires. The study revealed that the major insect pests attacking cucurbits were fruit fly, red pumpkin beetle, aphid, whitefly, epilachna beetle, cucurbit sting bug, cutworm, and blister beetle. The majority of farmers responded that fruit fly was the most prevalent insect pest, followed by aphid and red pumpkin beetle. Most of the farmers used chemical methods, that includes biological, mechanical, and cultural techniques to control the insects. For the mechanical method, they used sex-pheromone traps i.e. cue-lure. Among botanical pesticides, Neem (Azadirachta indica), Malabar Nut (Justicia adhatoda), Chinaberry (Melia azedarch), Mugwort (Artemisia spp.) were used. Commonly used insecticides by farmers were Cypermethrin, Dimethoate, Malathion, and Endosulfan. The indiscriminate use of chemical pesticides resulted in pest resistance, resurgence, and sometimes outbreak of insect pests. Majority of farmers were using chemical methods to control pests. Apart from this, Integrated Pest Management (IPM) was also adopted for good agricultural practices (GAP) to prevent chemical hazards on human health and the environment. To control insect pests, trained farmers should be encouraged to follow the sanitation of fields and protection of natural enemies by avoiding the use of pesticides a long as possible.
\end{abstract}

Keywords: cucurbits, good agricultural practices, insect pest, management

Received 17 August 2020 | Revised 26 October 2020 | Accepted 9 November 2020

\section{Introduction}

Cucurbits are warm-weather crops that are sown, grown, and harvested over spring, summer, and autumn. Cucurbit includes bottle gourd, ash gourd, cucumber, sponge gourd, snake gourd, pumpkin, bitter gourd, ridge gourd, and summer squash. Cucurbits are commonly cultivated for commercial use for both food and recreational use. Owing to nutritional value, the market for

Corresponding author at: Himalayan College of Agricultural Science and Technology, Purbanchal University, Kathmandu, Nepal

E-mail address: subina.tri@gmail.com 
cucurbits is rising day by day. Farmers are involved in the production of both improved and local cucurbit varieties. However, because of major losses due to various insect pests, production has become risky. Insect pests will harm the cucurbits anywhere cultivated. One of the key constraints on commercial vegetable production is the prevalence of numerous major and minor insect pests that increase the quantity and consistency of crops. Productive and economic management of insect pests is necessary for the successful production of cucurbits [1]. Insect pest's occurrence in cucurbits is a serious problem in Lamjung, especially in cucumber, bottle gourd, squash, snake gourd, and pumpkin [2]. The extents of losses vary between 30\% - 100\% depending upon cucurbit species [1]. Among the many pest species, fruit fly and aphid were the most destructive ones. The most severe economic damage caused by the maggots of the fly was by feeding inside the fruits which made fruits unfit for consumption.

Adult fruit flies select soft and young fruits for ovipositor by puncturing the rind with their sharp ovipositor [3]. Due to fruit fly infestation, 73.83\% damage was reported from cucumber crop [4]. The red pumpkin beetle, (Aulacophora foveicollis Lucas) is also a serious pest of cucurbits, may cause up to $70 \%$ damage on leaves and $60 \%$ damage on flowers of cucurbits crop in west Bengal [5]. Epilachna beetle, leaf roller, green semi looper, aphids and white fly etc. were also found to be destructive pest on cucurbits [6] (Barma and Jha, 2013; Barma and Jha, 2011 and Jha, 2008 etc). From these reports, it is clear that the attack on this insect pest is a key factor in reducing cucurbits crop quality and quantity. Despite the importance of cucurbits and severity of the insect pests, the management practices are still limited to frequent sprays of toxic chemical pesticides only. Both, overuse and misuse of insecticides, may lead to loss of insecticides due to the development of resistance [3]. Selection of inappropriate pesticides, incorrect time of application, and improper doses has resulted in high pesticide cost with little or no reduction in target pest. Extensive use of chemical pesticides causes financial burden both to poor farmers and country as a whole [7]. Farmers are using chemical pesticides instead of bio pesticides which cause resurgence of resistant pest population and secondary pest outbreaks, loss of biodiversity and reduction on crop yield and lower the net profit in long term. Good Agricultural practices (GAP) are important for quality and hygienic produce. So, it is very necessary to implement vegetable IPM activities through farmer field school (FFS) to reduce chemical pesticide hazards on human health and the environment [8]. Keeping this fact in mind, study was carried out to identify the common insect pests prevailing in the cucurbits to identify their management practices and suggesting them the best measures to improve cucurbit cultivation in Lamjung District representing 4 VDCs (Village Development Committees) namely Dhamilikuwa, Baanjhakhet, Khudi, Tarkughatand Gairi. The aim of this survey is to understand the individual viewpoints of vegetable farmers on the major constraints of cucurbit cultivation, infestation, and various management practices adopted by farmers for pest management. An understanding of the knowledge, interpretation, and strategies of farmers to solve problems helps to undertake research including the involvement of farmers and that will 
lead to an appropriate and efficient choice for pest control that meets the needs of farmers. [9]. Besides, farmers' current perceptions of insect control practices for pests and available management methods will provide important data for the effective implementation of the strategy for pest management and also contribute to rural development [10]. To establish integrated and effective pest management strategies in the vegetable production system, adequate information on the participatory pest management strategies of farmers is very relevant. Therefore, the objective of this study is to investigate the perceptions, knowledge, and insect pest management practices of farmers in fruit vegetable cultivation in Lamjung. This will help to assess any failure in the system of small-scale producers to provide the necessary information to facilitate the implementation of control strategies in the system of vegetable production.

\section{Materials and Methods}

\subsection{Selection of Study Area}

Household and field surveys were conducted from June 23 to August 25, 2018. Four representative VDCs (Village Development Committees) namely Dhamilikuwa $\left(28.0891^{\circ} \mathrm{N}\right.$, $84.4750^{\circ}$ E), Baanjhakhet, Khudi $\left(28.3801^{\circ} \mathrm{N}, 84.3226^{\circ} \mathrm{E}\right)$, Tarkughatand Gairi VDCs of Lamjung District $\left(28^{\circ} 12^{\prime} 35.7^{\prime \prime} \mathrm{N} 84^{\circ} 21.828^{\prime} \mathrm{E}\right)$ were selected for the survey. A wide range of cucurbit cultivators was collected in different agro-ecological areas within the region, i.e. Lamjung that represents the mid-hills of Nepal, spanning from tropical and geo-ecological trans-Himalayan belts including the country's geographic core.

\subsection{Population Sample and Sampling Technique}

A total of 95 households from the total respondents were computed by simple random sampling methodology as the sample size for the study area. Thus, in this way of fifty cucurbit growers were selected from Dhamilikuwa, twenty from Baanjhakhet, five from Khudi, ten from Tarkughat, and ten from Gairi and the sampling framework was prepared.

\subsection{Data Collection}

Before visiting the field, the potential area for cucurbit cultivation was identified from secondary data and literature review. The primary data were collected using a semi-structured questionnaire, self-administered surveys, interviews, field observation, and experiments. After the respondent had provided their responses, their recommendations and suggestions were used to create the final semi-structured questionnaire (also known as the mixed questionnaire), including closed and open questions. While executing the questionnaire with each interview, the questions have been either clarified in Nepali or Nepal Bhasa when needed in most cases as the majority of the respondents were illiterate or merely literate. After the informed consent, all the data were collected from face to face interviews. By personal communication, the study's goal 
was conveyed to these respondents. Additionally, follow-up phone calls and visits were made to the respondents if necessary, to retrieve any necessary information even after the actual interview. On the basis of inclusion and exclusion the farmers who did not grow cucurbits over the last one year were not selected. However, household head were the targeted respondents, although adult/young who were familiar with cucurbit production in the household were also considered for the interviewed. Including the basic information on socio-economic statuses such as age, gender, educational level, occupation, landholding, the technical aspect of insect pest occurrence and their management practices were collected from each individual. Different secondary information was obtained from the publication of the District Agriculture Development Office (DADO) and the regional and central level Organizations such as the Central Bureau of Statistics Office (CBS), Ministry of Agriculture, and Livestock Development (MoAD). Information was also collected from published and unpublished literature such as annual reports, research papers, articles, and books. After the collection of data, the data were converted into tabulation formats. The data obtained were presented in a bar diagram, pie charts, Tables, and graphs. After the completion of the survey, collected data were analyzed by using software like Microsoft excel.

\subsection{Data Analysis}

To maintain the significance of results, data was collected and coded, arranged in different forms as charts, Tables, diagram, pie charts and graphs, Descriptive statistical tools like; mean, percentage (\%) were used for data analysis. Collected data analyzed by using MS-excel, both quantitative and qualitative. The findings were logically interpreted and the necessary conclusions were drawn.

\section{Results and Discussion}

\subsection{Socio-Economic Characteristics of Respondents}

\subsubsection{Gender of respondents}

Of the 95 respondents, the overwhelming majority (62\%) were males, while about $38 \%$ were women. It showed that the male population was actively engaged in agriculture. Female respondents were engaged in housekeeping and care-giving practices. It was observed that females were illiterate so that they could not distinguish the forms of helpful and harmful pests the preparations and usefulness of botanical pesticides. Appropriate usage of chemical fertilizers and organic manures helps boost farm productivity while preserving soil fertility [5]. Males dominated overall farming in Brazil, as reported in a study [6]. Male farmers have been reported to be more aware of the adverse impact on the human safety of pesticides than female farmers [7]. Females also have a specific vulnerability to pesticides because of their physiological, lifestyle, and behavior [8]. Females of the population are more vulnerable to exposure to the infected food, consuming contaminated plants and goods, washing contaminated clothes, 
consuming polluted water, and heavy use of multiple pesticides in agriculture because of long working hours of the earliest age or frequent exposures, at work and in the home [9]. The transfer of agricultural chemicals in breast milk is a problem, too - an approximate 12 times the acceptable level of DDT is supplied to the average child in Delhi, India [10].

The heavy use of pesticides naturally presents significant health risks to farm female and their families. When chemicals applications are involved, their role in pesticide-related activities multiplies. From the study, most males are interested in the practice, techniques, and management of pest management. Where only a few females are involved in management. This is due to a lack of awareness, expertise in management and exposure to chemical use.

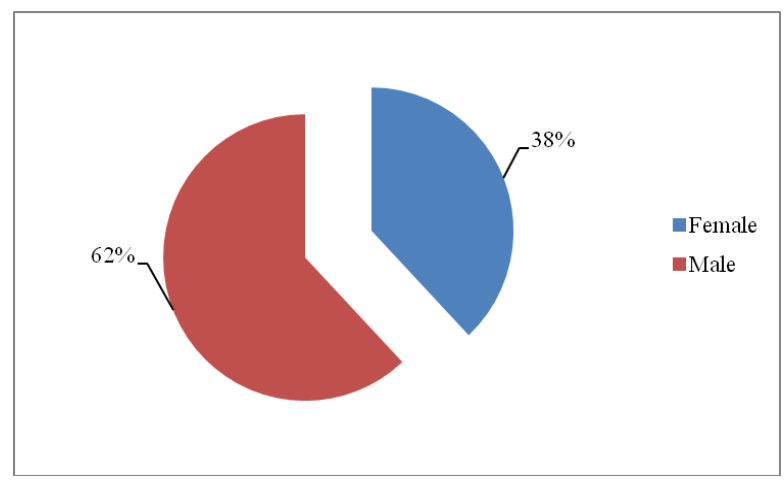

Source: Field Survey, 2018

Figure 1. Gender of Respondents

\subsubsection{Age of respondent}

Based on age, the highest number of respondents fall in the age group of 30-40 years (33\%) followed by age group of $40-50$ years (25\%) while lowest was in the age group above 60 years (5\%). It shows that the active member falls under the age group between 30-40 years

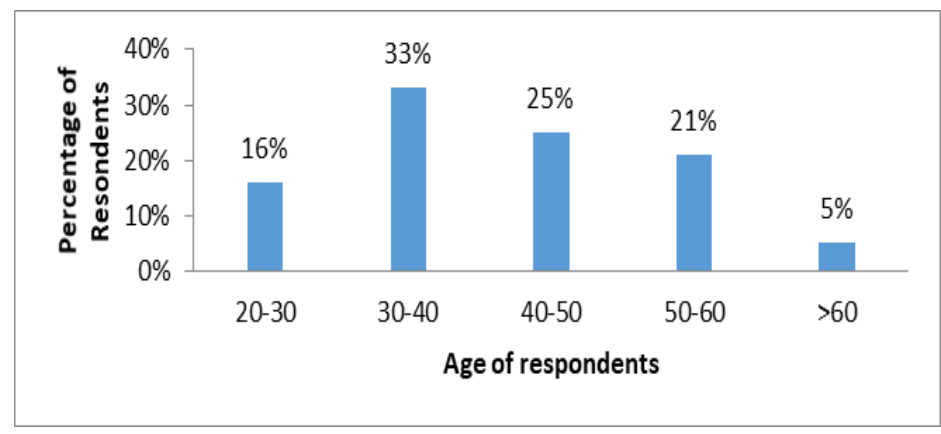

Source: Field Survey, 2018

Figure 2. Age of Respondents

\subsubsection{Education status}

Education helps a farmer to take risks and adoption of new technology. Gross and Tales [11] found that the distinction between qualified farmers and the untrained was the adoption of proposed farming activities. The educational level of the respondents was categorized into four 
groups: no formal education, primary, secondary, and above secondary education. About $40 \%$ of the respondents did not have formal education, $14 \%$ had primary level education, $28 \%$ had secondary and $18 \%$ had above secondary level education.

Pesticide knowledge attitudes and patterns of application are relevant. Agricultural workers with limited knowledge may be at greater risk while using pesticides, perhaps because of difficulties in understanding the usage and safety instructions on the product label [12]. Farmers most often have little awareness of pest management and the ramifications of pesticide use, while many still lack personal protective devices (PPDs) even if they are aware of the harmful consequence's pesticides can cause [13].

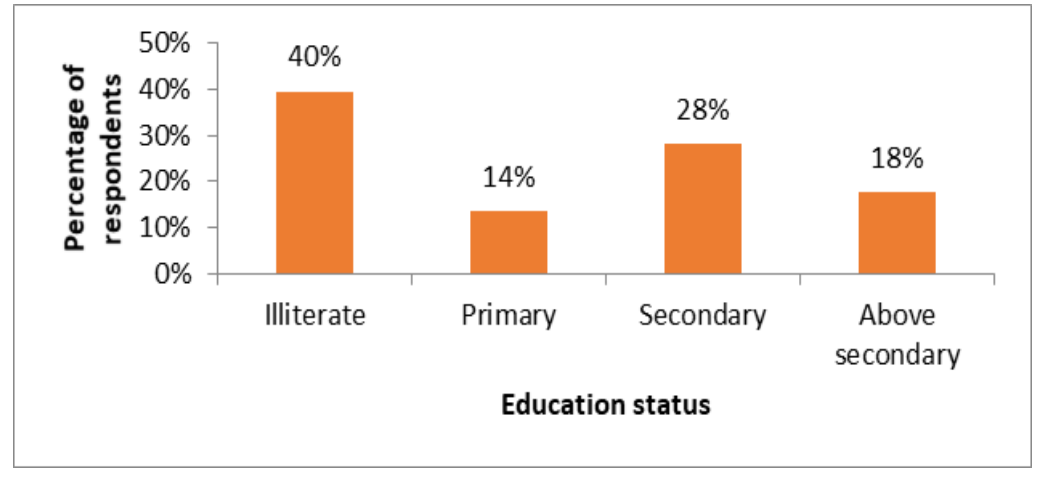

Source: Field Survey, 2018

Figure 3. Education Status of Respondents

\subsubsection{Occupation of respondents}

It was found that the major occupation of the respondents was agriculture which accounted for $56 \%$. Similarly, $28 \%$ of them were in government service, while $16 \%$ were engaged in business. Almost $66 \%$ of rural people are involved in agriculture at national level [14].

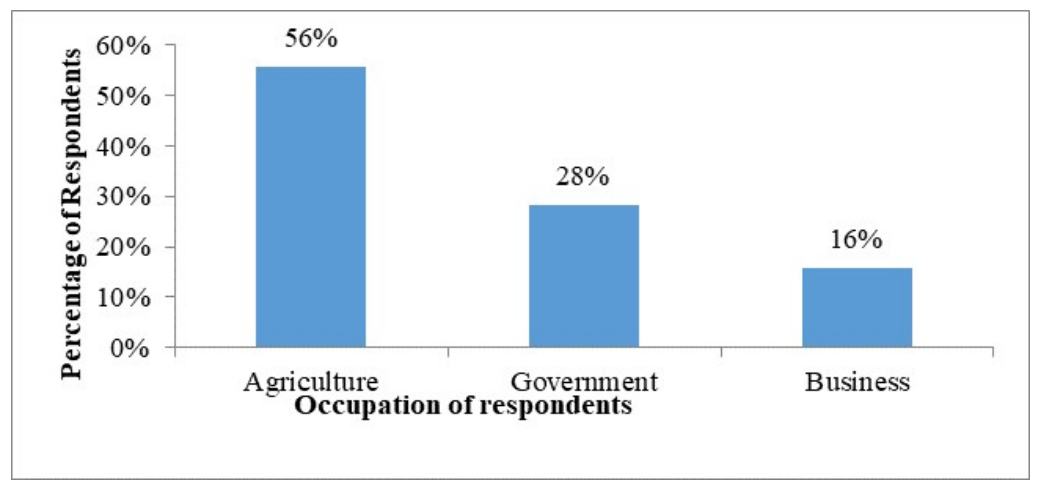

Source: Field Survey, 2018

Figure 4. Occupation of the Respondents

\subsubsection{Land holding}

The largest landholdings per household were from 0.3 to 0.4 ha. Farmers of Dhamilikuwa had large land, followed by Bhaajakhet and Tarkughat. Figure 5 showed that $47 \%$ of the 
respondents had large land holding (0.3-0.4 hectares), whereas, $41 \%$ of the respondents had medium landholding (0.2-0.3hectare) and 12\% had small landholdings (0.1-0.2 hectare). The landholding is categorized into three types i.e. Smallholding (0.1-0.2ha), medium holding (0.2$0.3 \mathrm{ha}$ ), and large holding (0.3-0.4). $45 \%$ of farmers with a cumulative land of under 0.5 ha still share $13 \%[14]$.

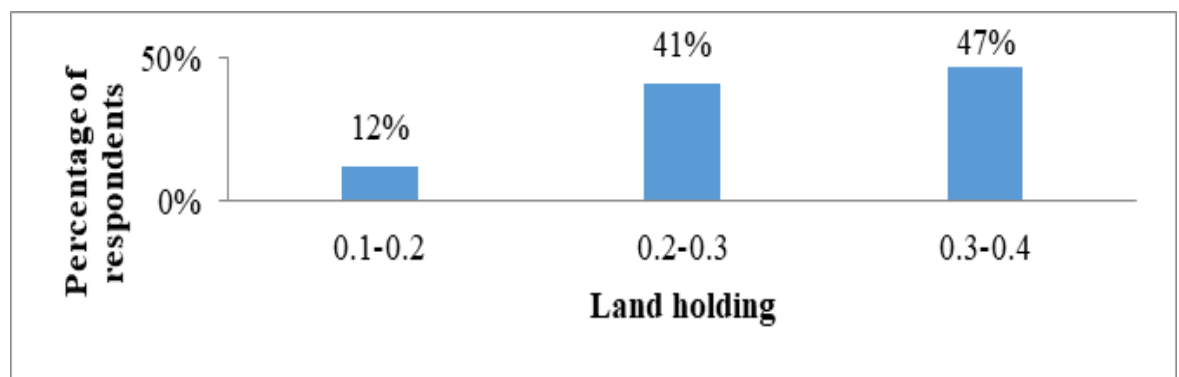

Source: Field Survey, 2018

Figure 5. Land Holding of Respondents

\subsubsection{Irrigation facility}

According to the survey, $67 \%$ of respondents had irrigation facilities, while $33 \%$ had not. The main source of irrigation was the river/stream. The population density of eggs and larvae of the insects was mentioned to be high in rain-fed conditions then irrigated. The rain-fed condition favors the growth of insect infestations. Therefore, irrigation facilities control insect pests in cucurbit crops. WECS [16] estimates that some irrigation of $42 \%$ of the cultivated region, but just $17 \%$ of the cultivated field has irrigation of some type all year round.

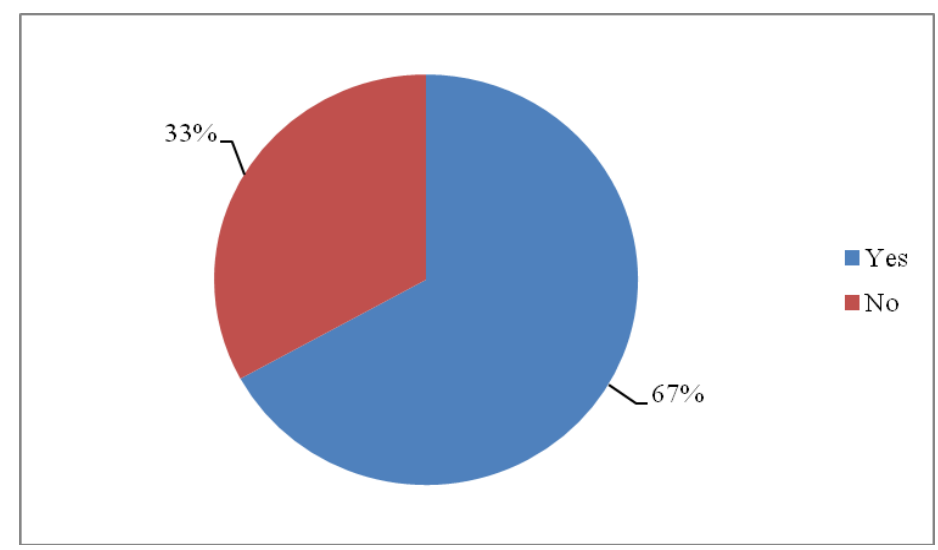

Source: Field Survey, 2018

Figure 6. Irrigation Facility of the Respondents

\subsubsection{Source of seed}

The majority of the farmers (84\%) got the vegetable seeds from the agro-vet, $11 \%$ from DADO and $5 \%$ from NGO/INGO. They told that agro-vet provided them good quality seeds so they prefer buying seeds from agro-vets. 
Table 1. Sources of seeds of the respondents

\begin{tabular}{lcc}
\hline \multicolumn{1}{c}{ Source } & Frequency & Percentage (\%) \\
\hline Agro-vet & 80 & 84 \\
NGO/INGO & 5 & 5 \\
DADO & 10 & 11 \\
Total & 95 & 100 \\
\hline
\end{tabular}

Source: Field Survey, 2018

\subsection{Major Constraints of Cucurbit Farming}

Farmers had faced many challenges during cucurbit production, i.e. insect pests, disease, quality of seed, and marketing. Among them, $48 \%$ of farmers responded that damage was due to insect pests, such as fruit flies, red pumpkin beetle, and aphids. Damage due to diseases, such as downy mildew, alternaria leaf spot, bacterial wilt, virus, Cercospora leaf spot, scab, and powdery mildew were major problems faced by $25 \%$ of the respondents. Twenty-one percent responded that due to lack of proper knowledge on quality seed, they were facing problems in production. Only 5\% were facing problem in marketing. Rajbhandari and K.C. [17], reported a similar field observation, as insects pest and disease were major constraints which support the present study. When organic fertilizer, water supplies, and other preventive measure do not meet the demand for crop water, this undoubtedly affects the crop growth and ultimately the production of crops [18].

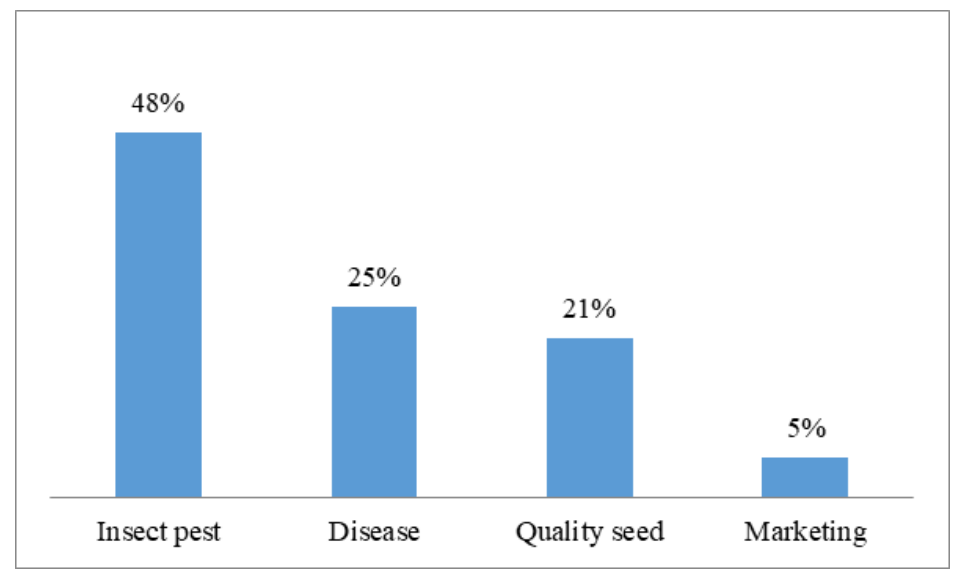

Source: Field Survey, 2018

Figure 7. Major Constraints of Cucurbit Production

\subsection{Infestation of Insect Pests in Cucurbits}

According to the respondents, different insect pests had different status each year. The result showed that the status of fruit fly (Bactrocera cucurbitae) was in increasing trend as reported by $29 \%$ of respondents. Bacrocera cucurbitae (Fruit fly) is a substantial insect pest in cucurbitacae [19]. 
Fruit flies attacked more during the fruiting stage of cucurbit crops. Similarly, $16 \%$ of respondents said that aphid was also in an increasing trend. Fourteen percent of losses were caused by red pumpkin beetle (Aulacophora foveicollis), followed by $12 \%$ losses by blister beetle, $9 \%$ by cucurbit sting bug (Coridius janus), $8 \%$ by cutworm (Agrotis spp.), $6 \%$ by epilachna beetle(Epilachna chrysomelina) and only $5 \%$ by whitefly (Bemisia tabaci). In seedling, vegetative and reproductive processes, the red pumpkin beetles were troublesome. Compared to fruit flies, aphids and red pumpkin beetles, cutworms, epilachna beetles and whitefly were less evident. The red pumpkin beetle, (Aulacophora foveicollis Lucas), can inflict up to $70 \%$ damage to leaven and $60 \%$ harm to cucumber flowers [19].

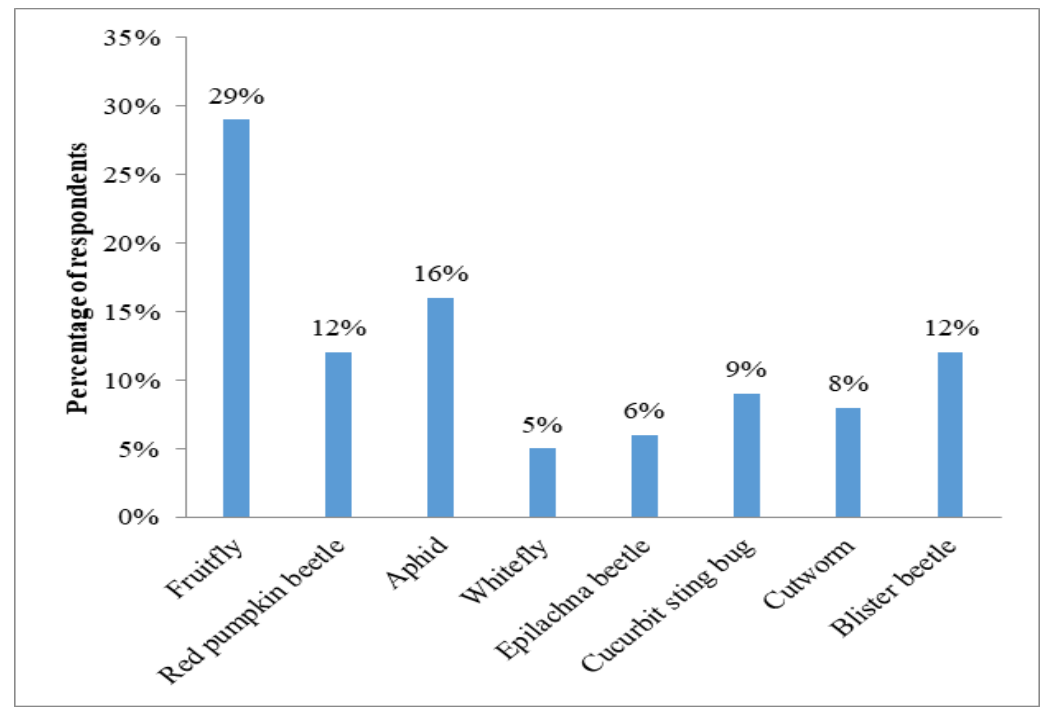

Source: Field survey, 2018

Figure 8. Infestation of Major Insect Pests in Cucurbit

\subsection{Management Practices Adopted by The Farmers}

Different methods of insect pest management were found to be adopted by the farmers of Lamjung district, such as chemical, mechanical, botanical, etc. Among the 95 respondents surveyed, $35 \%$ of respondents used a chemical method of pest management. Varied chemicals, such as Nuvan, Kingvan, Doom, Roger, Goldcyp-10, Sherpa-10, etc., were found to be used by the farmers. Similarly, mechanical practices like mechanical destructions of pests, use of traps and lures were also in primary practices among $26 \%$ of farmers. Similarly, $24 \%$ of the farmers used bio-pesticides or homemade botanical pesticides prepared from locally available materials, like neem, bojho, tetipati, bakaino, etc. Cultural practices, such as field sanitation, weeding, mulching, inter-cropping was adopted by $15 \%$ of the farmers. The decomposition of residues from top and bottom crops is facilitated by the intensive cultivation and shredding of crop residue. The influence of these insects-pests can be restricted by early plowing and unloading that removes unnecessary weeds and discourages the spreading of maggots, the delayed planting, and higher seed production [20]. Small-scale cucurbit cultivations, the use of row covers, screens, or cones for trapping of insects may shield young plants by mechanical means 
[21]. Knowledge of nutrient relationships and refine approaches will easily contribute to better returns and high productivity [22]. Knowledge of the nutrients required at all stages of growth and an understanding of the soil's ability to provide the necessary nutrients are crucial for profitable crop production [23].

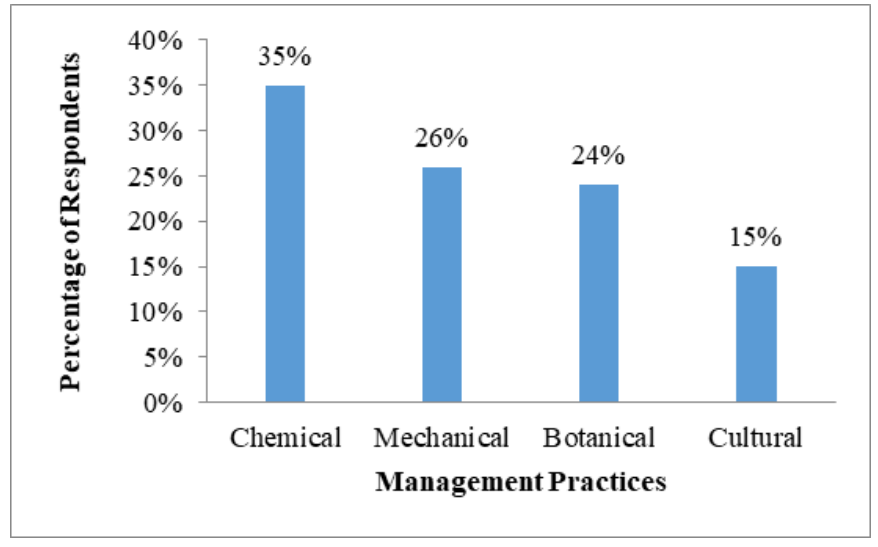

Source: Field Survey, 2018

Figure 9. Management Practices Adopted by the Farmers

\subsubsection{Botanical method}

Plant derivatives or photochemical provide an enticing option in managing phytopathogenic fungi to potentially synthetic fungicides because they are an abundant source of bioactive compounds [24]. People have been using plant and plant products for healing of various diseases as medicine without knowing their chemical constituent and biological activities since ages [25]. Various botanical chemicals were used to control pests in agricultural populations.

Table 2. List of Commonly Used Resources for Botanical Treatments

\begin{tabular}{ccccc}
\hline SN & Local Name & Common Name & Scientific Name & Parts Used \\
\hline 1 & Neem & Neem & Azadiractaindica & Leaves, Seed \\
2 & Asuro & Malabar Nut & Justiciaadhatoda & Leaves \\
3 & Surti & Tobacco & Nicotianatabacum & Leaves, Stem \\
4 & Titepati & Mugwort & Artemisia spp. & Leaves \\
5 & Mewa & Papaya & Carica papaya & Leaves \\
6 & Bakaino & Chinaberry & Meliaazedarch & Leaves, Seed \\
7 & Sisnu & Stinging neetle & Urtiadioica & Leaves, Stem \\
8 & Khursani & Chilly & Capsicum annum & Fruits \\
9 & Lasun & Garlic & Allium sativum & Cloves \\
10 & Bojho & Sweet flag & Acoruscalamus & Rhizome \\
11 & Timur & Nepali pepper & Xanthoxylumspp & Seeds \\
12 & Banmara & Micanamicrantha & Agretinaadenophora & Leaves, Stem \\
\hline
\end{tabular}

Source: Field Survey, 2018

In Nepal, there are currently 324 plant species with any form of pesticide [26] characteristics. Local people have indigenous knowledge of the available forest resources and their botanical 
use on pesticides in combination with agricultural production [27]. The effective implementation of integrated pesticides [28] would be encouraged by farmers to recognize biological surveillance through fieldwork. As secondary plant metabolites, Botanicals are an enticing and beneficial alternative for the management of pesticides [29]. Therefore, botanical secondary compounds are a wide reservoir of pesticide active chemicals [30].

\subsubsection{Chemical method}

The result showed that farmers seldom used bio-pesticides for pest management. With the growing trend of commercial vegetable production in Nepal, the use of pesticides on vegetables has increased dramatically in recent years [31]. The extremely hazardous pesticides are being used in vegetables which are banned by the Government of Nepal [32]. In Lamjung district, Dichlorvos was highly preferred chemical pesticides by farmers, followed by Cypermethrin. A recent report revealed that the average pesticide used in Nepal is approximately $396 \mathrm{gm} / \mathrm{ha}$ [33], and that was only $142 \mathrm{gm} / \mathrm{ha}$ in 1995 [34].

Table 3. Major Chemicals Used by The Farmers

\begin{tabular}{lllc}
\hline \multicolumn{1}{c}{ Trade name } & \multicolumn{1}{c}{ Common name } & Formulation & Frequency \\
\hline Nuvan, Kingvan, Doom & Dichlorvos & $80 \% \mathrm{EC}$ & 34 \\
Goldcyp-10, Sherpa-10 & Cypermethrin & $10 \% \mathrm{EC}$ & 20 \\
Roger, Rogoban & Dimethoate & $(30 \%) \mathrm{EC}$ & 17 \\
Carbine & Chlorphyriphos + & $(50 \%+5 \%)$ & 9 \\
Suryathion & Cypermethrin & EC & 7 \\
Metacid & Malathion & $50 \% \mathrm{EC}$ & 5 \\
Thiodan & Methyl parathion & $50 \% \mathrm{EC}$ & 3 \\
\hline
\end{tabular}

Source: Field Survey, 2018

\subsubsection{Pesticide application interval}

Almost all the respondents were using chemical pesticides at different time intervals. Most of the respondents (39\%) applied pesticides depending upon the presence of insect pests and their numbers. Many respondents (29\%) applied pesticides at 10 days intervals, followed by $19 \%$ who applied pesticides at 1-5days intervals and only $13 \%$ of the respondents were found to be making an interval of 5-10 days. Frequent application of pesticides is hazardous to the environment and human health. The frequent application of pesticides by the farmers might be due to a lack of proper knowledge of the negative effects of pesticides. Waichman [35] reported some farmers to spray insecticides every 3-5 days in Brazil, pesticide spraying frequency ranged from once every 3 days to once a week. 


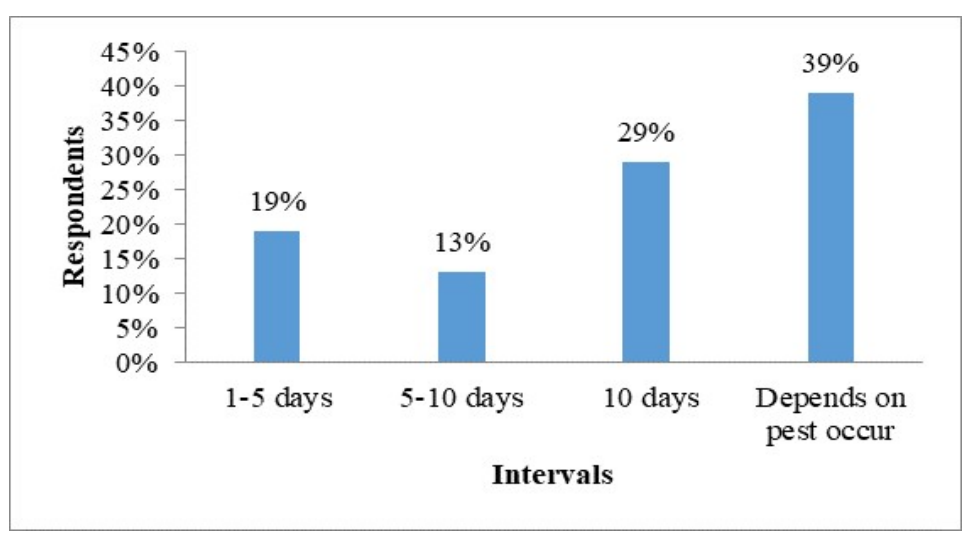

Source: Field Survey, 2018

Figure 10. Pesticide Application Intervals by the Respondents

\subsubsection{Dose of chemical pesticides}

The consumption pattern of pesticides in Nepal is $142 \mathrm{~g}$ a.i./ha [36]. Most of the respondents, $75 \%$, were found using the recommended dose of the chemical pesticides, but only $25 \%$ used more than the recommended dose. The majority of respondents took information about the application of chemical pesticides from Agro-vets and neighbors. Profound experiments demonstrate that the large doses/concentration of pesticides by farmers have acute impacts, although small intake doses contribute for a long period to chronic impact [37].

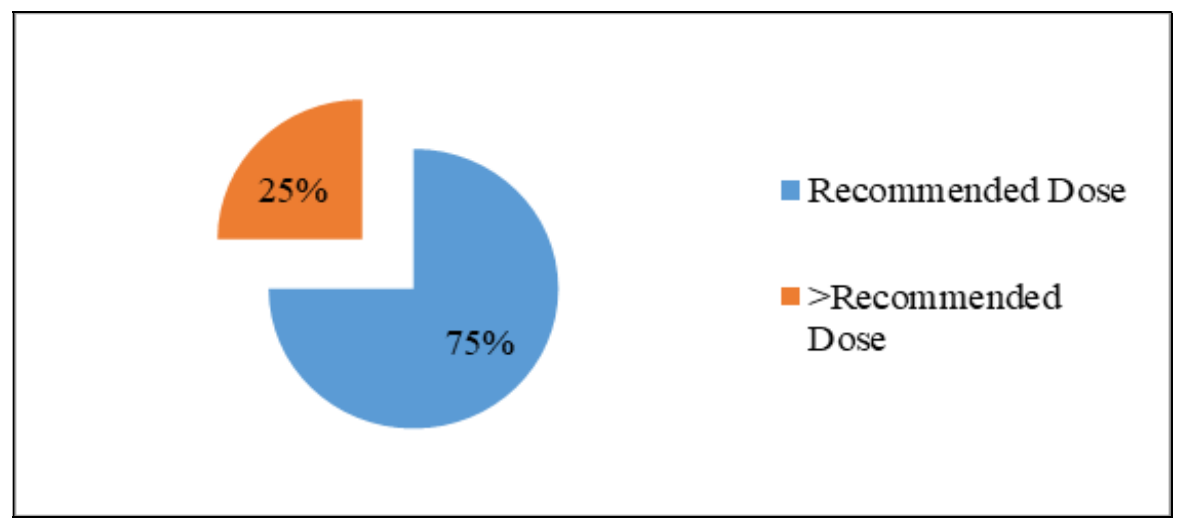

Source: Field Survey, 2018

Figure 11. Dose of Chemical Pesticides Used by the Farmers

\subsubsection{Safe disposal of chemical pesticides}

Many respondents (58\%) have not disposed of chemical pesticides safely. After use, they then throw packages and bottles carelessly on the river/stream or anywhere which may present a danger to animal welfare. And by burying or destroying it, only $42 \%$ of the respondents had disposed safely. The more irrigation, the fewer infestations there will be. About $42 \%$ of those surveyed had washed the pesticide water bottle/spray in the local water bodies. The aquatic creatures are being poisoned [38]. Palikhe [39] reports that more than $60 \%$ of the pesticide used remains a challenge to the terrestrial and aquatic biosphere in a soil environment. For more than nine years, the residual effects of certain chlorinated hydrocarbons such as chlordane, BHC, 
DDT, and aldrin persist in the soil [40]. The application of pesticides often presents risks for people's safety and the environment [41].

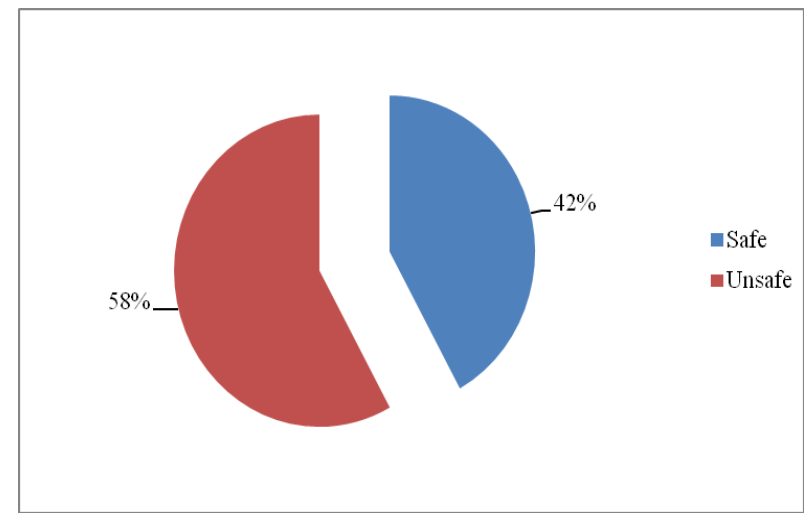

Source: Field Survey, 2018

Figure 12. Disposal of Chemical Pesticides

\subsubsection{Use of protective measures}

Of the total respondents using chemical pesticides, $70 \%$ of the respondents used masks, gloves, boots, and eyeglasses as protective measures, while 30\% of them did not use protective measures. Farmers provided no guidance or professional assistance with pesticide use and proper handling. Almost all the farmers agreed that they impose of pesticides caused some risk to human health and the environment. A large majority (>90\%) figured pesticides hazardous to human safety but fewer than $20 \%$ used caps, impermeable clothing, or gloves throughout the application of the pesticide [42].

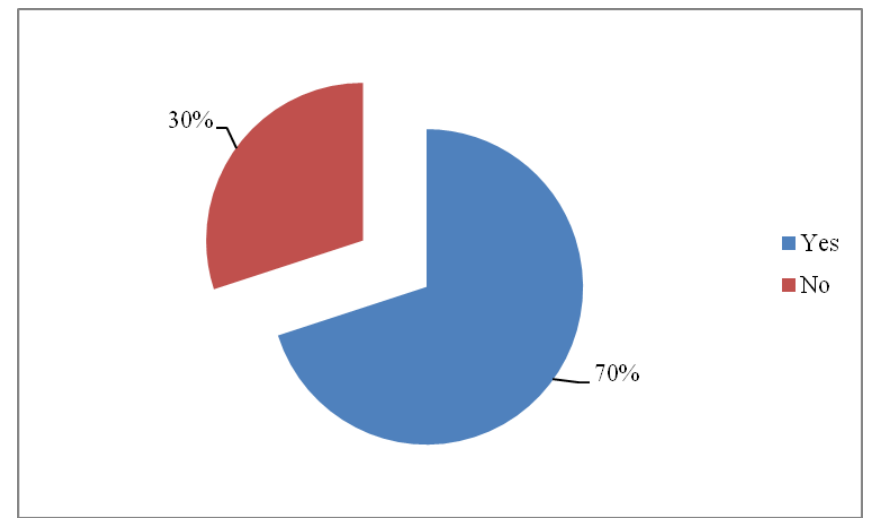

Source: Field Survey, 2018

Figure 13. Use of Protective Measures

\subsection{Participation in Training}

Many farmer's training and events were organized in the Lamjung district. CHESS Nepal, ACIAR, Nepal Agroforestry Foundation (NAF) have conducted training on vegetable-farming, seed production, and awareness program for farmers about IPM farming to encourage them. Though many organizations had conducted training; they didn't have a change in attitude 
regarding farming with new techniques. They followed the traditional farming methods. Almost all the respondents were found to be using the traditional method. They were not utilizing the knowledge gained through training.

\subsection{Understanding of IPM by the Respondents}

Out of 95 respondents, 52\% knew IPM (Integrated Pest Management), while 32\% of respondents were unknown about it. The majority of the respondents had taken knowledge of IPM from different pieces of training. From the survey, it was revealed that the respondent gets knowledge related IPM because of different programs oriented by FFS (Farmer's Field School) at Lamjung. Many IPM farmers have shared their awareness regarding their field operations, their decisions on pesticides, and their involvement in community development projects. Economic conservation, substantial advancement, and food security might even be attributed to proper knowledge among farmers can maintain environmental stability [43]. Women farmers have thought that their faith had risen even more than before [44].

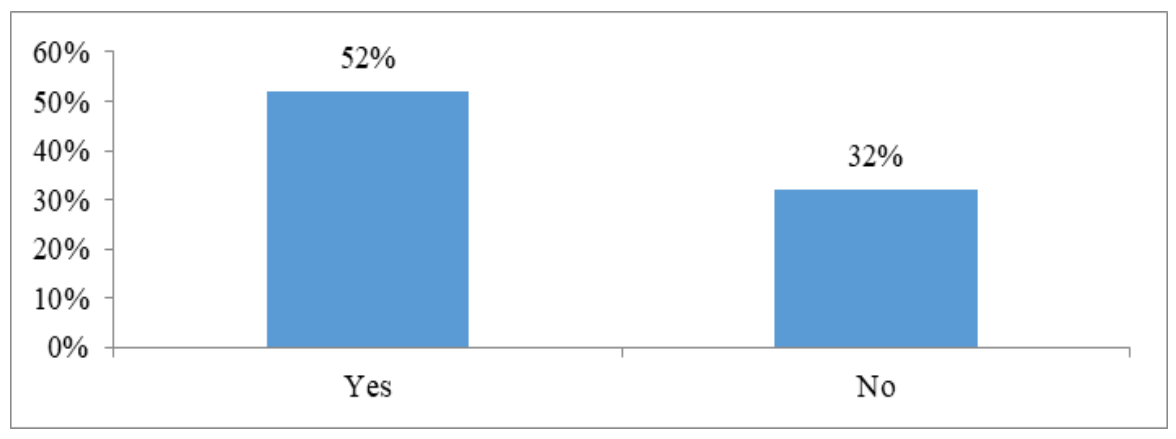

Source: Field Survey, 2018

Figure 14. Understanding of IPM by the Respondents

\subsection{Government Intervention}

Of the overall respondents, $60 \%$ reported the presence of government bodies. We have reported that they get slight government support. Just $40 \%$ thought that the government had ignored them.

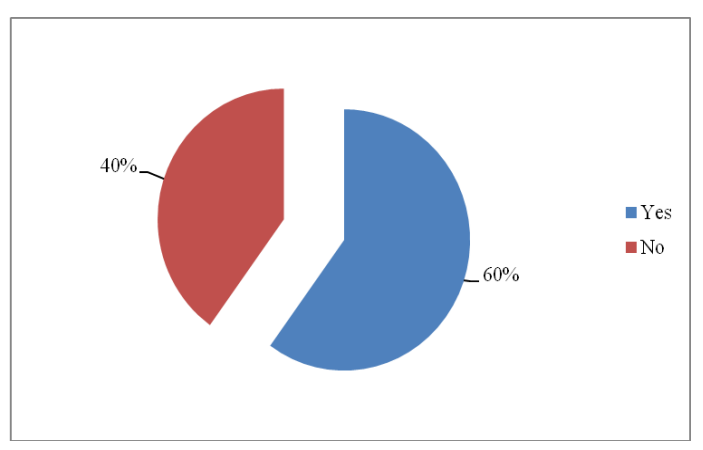

Source: Field Survey, 2018

Figure 15. Government intervention in farm communities 


\section{Conclusion}

The study found that the major occupation of farmers was agriculture. Most of the farmers were more aware of the damage to insect pests in their crops, but they had little knowledge of the particular insect that causes harm to the crop. One of the challenging problems in the growth of agriculture was a poor literacy rate. Farmers experienced heavy economic losses from insects namely pumpkin beetle, aphid, fruit flies, cucurbit stink bug and epilachna beetle. On fruit flies' farmers are facing big challenge to manage them. Most of the farmers used chemical methods of pest management in Khudi, Tarkughat, and Baanjhakheet. In their knowledge of pest detection, collection of suitable pesticides, measurement and use of the correct dosage and handling procedures, and safety measures while handling pesticides, this has been an obstacle. Only few farmers were aware of IPM methods. The study suggests that a routine survey of insect pest's density should be carried out by the concerned institution to detect early any potentially risky insects for proper and timely management of insect pests. Therefore, in the area of research, there is a great need to minimize losses. Farmers in the study area do not receive adequate instruction, technical advice, and support from the government, organizations, and NGOs / INGOs. To achieve any level of pesticides, farmers need formal and informal training on the proper diagnosis of damage caused by many abiotic as well as biotic factors so that misuse may be reduced. The government should restrict the pesticides use by imposing high taxes on chemicals and subsidies for eco-friendly pest management. Efforts should be focused on developing and implementing eco-friendly IPM methods.

\section{Acknowledgement}

The authors were highly thankful to those farmers who directly involved in this survey for completion of this study.

\section{Conflicts of Interest}

The authors declare that there is no conflict of interest.

\section{REFERENCES}

[1] N. P. S, Dhillon and T. C. Wehner, "Host-plant resistance to insects in cucurbits germplasm resources, genetics and breeding," Tropical Pest Management, vol. 37, no.4, pp. 421-428, 1991. doi: https://doi.org/10.1080/09670879109371628

[2] Y. D. Gc and C. K. Mandal, "Integrated management of fruit fly (Bactrocera cucurbitae) on bitter gourd (Momordicha charantia) during the summer of 1998/99," IAAS Res. Rep., (1995-2000). pp. 171-175, 2000.

[3] D. Gupta and A. K. Verma, "Population fluctuations of the maggots of fruit flies Dacus cucurbitae Coquillett and D. tau (Walker) infesting cucurbitaceous crops," Adv. Pl. Sci., vol. 5, no. 2, pp. 518-523, 1992. doi: https://doi.org/10.1673/15362442(2005)5[1:TMFFBC]2.0.CO;2 
[4] N. K. K. Kumar, A. Verghese, B. Shivakumara, P. N. Krishnamoorthy, and H. R. Ranganath, "Relative incidence of Bactrocera cucurbitae(Coquillett) and Dacus ciliatus Loew on cucurbitaceous vegetables," Fruit Flies of Economic Importance: From basic to applied knowledge, Proceedings of the 7th International Symposium on Fruit Flies of Economic Importance 10-15 September 2006, Salvador, Brazil, pp. 249-253.

[5] S. Khan, N. A. Khan, G. Habib, M. S Qureshi, A. Sultan, "Assessment of Grewia oppositifolia leaves as crude protein supplement to low quality diets of goats," in Abdullah et al. (Eds). Proc. 1st Asia Dairy Goat, Kuala Lumpur, vol. 19, pp. 91-92, 2012.

[6] P. Barma and S. Jha, "Insect and non insect pests infesting pointed gourd (Trichosanthes dioica Roxb.)," in West Bengal. The Bioscan, vol. 8, pp. 537-543, 2013.

[7] S. Baker and B. K. Gyawali, 1994,"Promoting proper pesticide use in Nepal. Policy analysis in agriculture and related resource management research report 28,", Ministry of Agriculture, and Winrock International, Kathmandu, Nepal. vol. 18, pp. 5-10.

[8] B. P. Yadav, "Impact of integrated pest management practices (IPM) in vegetable crops of Nepal: Opportunities and challenges," in Abstracts of International Conference on Biodiversity, Climate Change Assessment and Impacts on Livelihood. Status and future potential, Pesticide Science, vol. 17, pp. 559-578, 2017.

[9] J. K. O. Ampofo, "Utilizing host plant restance in integrated pest management (IPM) systems for the small scale farmer in Africa," Integrating biological control and host plant resistance, vol.16, pp. 38-45,1996.

[10] T. Gabriel, "Pest control, pest management, and the 'human factor," Tropical Pest Management, vol. 35, pp. 254-256,1989.

[11] J. Shrestha, M. Kandel, S. Subedi and K. K. Shah, "Role of nutrients in rice (Oryza SativaL.): a review", Indian Journal, vol. 9, pp. 53-62, 2020.

[12] M. C. P. Recena, E. D. Caldas, D. X. Pires, and E. R. J. Pontes, "Pesticides exposure in Culturama, Brazil knowledge, attitudes, and practices," Environmental Research. Vol. 102, no. 2, pp. 230-236, 2006.

[13] W. Wang, J. Jin, R. He, and H. Gong, "Gender differences in pesticide use knowledge, risk awareness and practices in Chinese farmers," Science of the Total Environment, 22-28, 2017. doi: 10.1016/j.scitotenv.2017.03.053

[14] G. S. Berkowitz, J. G. Wetmur, E. Birman-Deych, J. Obel, R. H. Lapinski, J. H. Godbold, and M. S. Wolff, "In utero pesticide exposure, maternal paraoxonase activity, and head circumference," Environmental Health Perspectives. vol. 112, no. 3, pp. 388 -399, 2004. doi: 10.1289/ehp.6414.

[15] C. C. D. Tingle, J. A. Rother, C. F. Dewhurst, S. Lauer, and W. J. King, "Health and environmental effects of fipronil," Briefing paper for Pesticides Action Network, UK. vol. 22, pp. 103-118, 2000. doi: http://www.tfsp.info/assets/WIA_2015.pdf

[16] P. Ransom, "Women, pesticides and sustainable agriculture," Women's Caucus for the Earth Summit, CSD NGO Women's Caucus, vol. 6, pp. 29-39, 2002.

[17] Gross and Tales, "Characteristics associated with acceleration of recommended farm practices," Rural Sociology, vol. 17, no. 4, pp. 321- 327, 1952.

[18] Food and Agricultural Organization of the United Nations (FAO), "Pesticides: balancing crop protection and responsible use," Plant Production and Protection Division, Rome, Italy, 2014.

[19] N. Mahantesh and A. Singh, "A study on farmers' knowledge, perception and intensity of pesticide use in vegetable cultivation in Western Uttar Pradesh," Indian Agricultural Research Institute, vol. 32, pp. 63-69, 2009.

[20] D. P. Shrestha, "Trends, patterns and structure of economically active population, population monograph of Nepal, Kathmandu," Central Bureau of Statistics. vol. 1, no. 9, pp. 341-374, 2003. 
[21] CBS, "National Living Standard Survey," Central Bureau of Statistics, NPC, P. S. Bhandari, 2012.

[22] WECS, "Water Resource Strategy Nepal. Kathmandu: Water and Energy Commission Secretariat," 2003.

[23] Jyoti K. C. and B. P. Rajbhandari, "Major insect pests and diseases of cucurbits and their management under bio-intensive farming in Udayapur district," Nepalese Journal of Agricultural Sciences, vol. 13, pp. 87-88, 2015.

[24] K. C. S, K. K. Shah, N. Baidhya, P. Neupane, S. Pokhrel, K. Upadhyay, and J. Shrestha, "Evaluation of seedling growth of rice (Oryza sativa L.) genotypes under water stress and non-stress conditions," Archives of Agriculture and Environmental Science, vol. 5, no. 2, pp. 174-178, 2020. doi: https://doi.org/10.26832/24566632.2020.0502014

[25] J. S. Choudhary, A. Kumari, B. Das, S. Maurya, and S. Kumar, "Diversity and population dynamic of fruit flies species in methyleugenol based parapheromone traps in Jharkhand region of India," The Ecoscan, vol. 1, pp. 57-60, 2012. doi: https://doi.org/10.1080/24701394.2017.1350952

[26] K. A. Sorensen, "Cucumber beetles, Coleoptera: Chrysomelidae. Greenshare Fact Sheets," University of Rhode Island Landscape Horticulture Program," 1999.

[27] R. Bessin, "Cucumber beetles. ENTFACT-311," College of Agriculture Food and Environment, University of Kentucky, Lexington, pp. 327-360, 2010.

[28] M. Pandey, J. Shrestha, S. Subedi, and K. K, Shah, "Role of nutrients in wheat (Triticum aestivum L.): A review," Tropical Agro biodiversity, vol. 1, no. 1, pp. 18-23, 2020. doi: https://trab.org.my/archives/1trab2020/1trab2020-18-23.pdf

[29] S. Shrestha, J. Shrestha, and K. K. Shah, "Non-timber Forest Products and their Role in the Livelihoods of People of Nepal: A Critical Reviews," Grassroots Journal of Natural Resources, vol. 3, no. 2, pp. 42-56, 2020. doi: https://doi.org/10.33002/nr2581.6853.03024

[30] M. Wink, "Production and application of phytochemical from an agricultural perspective," in T.A. van Beek and H. Breteler (eds), Proceedings of Phytochemical Society Europe: Phyto-chemistry and Agriculture, Clarendon Press, Oxford, vol 34: pp. 171-213, 1993. doi: https://doi.org/10.1007/978-1-4020-8992-3_12

[31] H. Timilsina, B. Modi, and R. Basnyat, "Phytochemical, Antimicrobial and Ethnobotanical Study of Calotropis gigantean," Journal of Health and Allied Sciences, vol. 10, no. 2, pp. 23-27, 2020. doi: https://doi.org/10.37107/jhas.136

[32] F.P. Neupane, "Integrated management of vegetable insects," CEAPRED, Bakhundol, Lalitpur, Nepal. vol. 31, no. 2, pp. 166-172, 2000.

[33] J. Shrestha, K. K. Shah, and K. Timsina, "Effects of different plant fertilizers on growth and productivity of rice (Oryza sativa L.): a review," International Journal of Global Science Research, vol. 7, no. 1, pp. 1291-1301, 2020. doi: https://doi.org/10.26540/ijgsr.v7.i1.2020.151

[34] N. S. Upadhyaya, "Experience of community IPM in Nepal. Country Report," Landschaftsökologieu and Umweltforschung, Braunschweig, Germany, vol. 5, no. 2, pp. 237, 2002. DOI: 10.3126/ijasbt.v5i2.17628

[35] J. S. McLaren, "Biologically active substances from higher plants: Status and future potential," Pesticide Science, vol. 17, pp. 559-578, 1986.

[36] J. A. Klocke, "Natural plant compounds useful in insect control," American Chemical Society Series, vol. 296, pp. 396-415, 1987.

[37] R. Maharjan, S. Aryal, B. P. Mainali, S. Bista, D. N. Manadhar, Y. P. Giri, and R. B. Paneru, "Survey on magnitude of pesticide use in vegetable crops," Proceedings of the Fourth National Workshop on Horticulture", National Agriculture Research Council, Nepal. vol. 1, pp. 291- 98, 2004. 
[38] P. Shrestha, P. Koirala, and A. S. Tamrakar, "Knowledge, practice and use of pesticides among commercial vegetables growers of Dhading district, Nepal," The journal of Agriculture and Environment, vol. 11, pp. 95-100, 2010.

[39] N. Giri, "Pesticide use and food safety in Kathmandu Valley, Nepal," Master Thesis, Institute of Soil Research University of Natural Resources and Life Sciences (BOKU), 2010.

[40] L. Dahal, "A study on pesticide pollution in Nepal," National Conservation Strategy Implementation Project, National Planning Commission, HMG Nepal, in collaboration with IUCN. Kathmandu, Nepal, 1995. doi: 10.12691/aees-2-2-5

[41] A. V. Waichman, E. Eve, and N. C. Silva-Nina, "Do farmers understand the information displayed on pesticide product labels: a key question to reduce pesticides exposure and risk of poisoning in the Brazilian Amazon," Crop Protection, vol. 26, no. 4, pp. 576-583, 2007. doi: 10.1016/j.cropro.2006.05.011

[42] S. Arora, A. K. Kanojia, and O. M. Bambawale, Pesticides: Status, Latest WHO Ranking, Regulation and Label Claims in India. New Delhi: National Centre for Integrated Pest management, Indian Council for Agriculture Research, 2011.

[43] M. C. Alavanja, J. A. Hopkin, and F. Kamel, "Health effects of chronic pesticide exposure: cancer and neurotoxicity," Ann. Rev. Pub. Health. vol.25, pp. 155-197, 2004. doi: https://doi.org/10.1146/annurev.publhealth.25.101802.123020

[44] D. P. Weston, J. You, and M. J. Lydy, "Distribution and toxicity of sediment-associated pesticides in agriculture-dominated water bodies of California's Central Valley," Environmental Science \& Technology, vol. 38, no. 10, pp. 2752-2759, 2004. 